\title{
Neural blockade in the evaluation and management of chronic pain: An overview
}

\author{
Ian Gilron MD MSC FRCPC
}

\begin{abstract}
Ian Gilron.
Neural blockade in the evaluation and management of chronic pain: An overview.

Pain Res Manage 2000;(5)1:93-100.

Local anesthetic and neurolytic nerve blocks have been used for over a century in the evaluation and management of chronic pain, despite a the dearth of evidence supporting their application. This article provides a general overview of the physiology and pharmacology of nerve blocks and suggests how they may affect pathophysiological mechanisms of chronic pain. Following a discussion of the rationale, clinical application and potential complications of nerve blocks, existing evidence of efficacy is reviewed. Further research evaluating mechanisms and efficacy of nerve blocks is vital to define their role in chronic pain management.
\end{abstract}

Key Words: Autonomic nerve block; Controlled clinical trials; Local anesthetic; Neoplasm; Nerve block; Pain pathophysiology; Pain therapy; Spinal cord; Treatment outcome

\section{Blocage neural dans l'évaluation et la prise en charge de la douleur chronique : une synthèse}

RÉSUMÉ : Les anesthésiants locaux et les blocages nerveux par neurolyse sont utilisés depuis plus d'un siècle pour l'évaluation et la prise en charge de la douleur chronique en dépit du manque de preuves en faveur de leur application. Le présent article donne un aperçu général de la physiologie et de la pharmacologie des blocages nerveux et propose plusieurs façons dont ils peuvent modifier les mécanismes physiologiques de la douleur chronique. À la suite d'une discussion sur le bien-fondé de leur application clinique, les complications potentielles des blocages nerveux et les preuves actuelles de leur efficacité sont passées en revue. Des recherches plus approfondies portant sur les mécanismes et l'efficacité des blocages nerveux sont primordiales afin de pouvoir définir correctement leur rôle dans la prise en charge de la douleur chronique.
$\mathrm{T}$ he neurophysiological effects and technical aspects of local anesthetic nerve blocks are well understood and have been described extensively (1). Neural blockade is a safe and highly effective technique, and is an important mo- dality in the management of acute postoperative pain (2). However, due to the complex nature of chronic pain and the obstacles to rigorous testing of the efficacy of nerve blocks in this setting, evidence supporting neural blockade in chronic

\footnotetext{
Pain and Neurosensory Mechanisms Branch, National Institute of Dental and Craniofacial Research, National Institutes of Health, Bethesda, Maryland, USA

Correspondence and reprints: Dr lan Gilron, Associate Medical Director, Pain Research Clinic, National Institutes of Health, Room 3C-434, Bethesda, Maryland 20892-1258. Telephone 301-496-5483,fax 301-402-4347, e-mail ig20v@nih.gov
} 


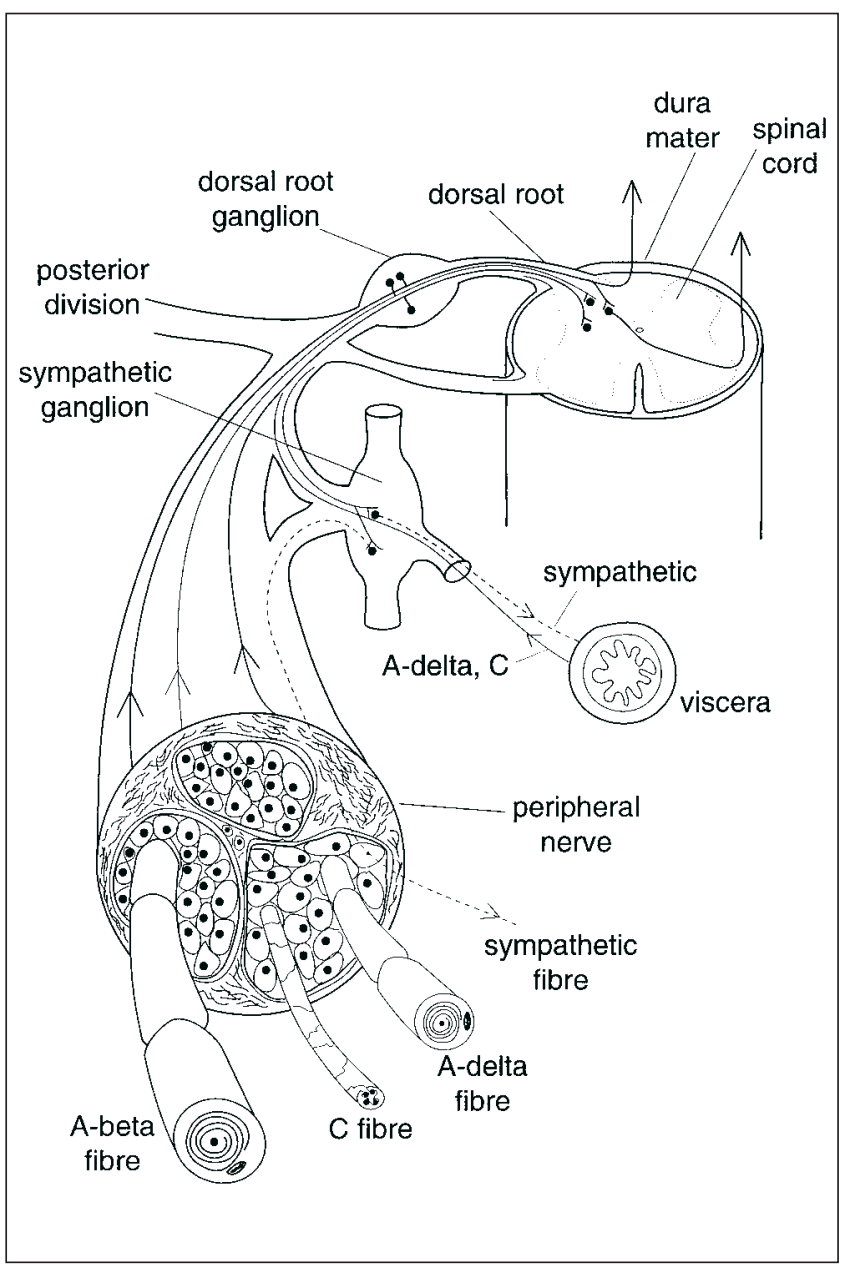

Figure 1) Anatomical basis of pain transmission. Nociceptive information is normally transmitted to the spinal cord via somatic and visceral nerves by A-delta and C afferent fibres whose cell bodies reside in the dorsal root ganglion. A-beta afferent and autonomic sympathetic efferent fibres course within these nerves and may also play a role in certain chronic pain conditions. Adapted with permission from reference 60

pain is limited. Nevertheless, percutaneous injections that block nerve conduction are commonly applied by anesthesiologists, neurosurgeons, physiatrists and dentists in the evaluation and management of chronic pain (3). This article provides a basic review of the physiology, pharmacology and fundamental clinical aspects of neural blockade for chronic pain and is intended as an introduction for readers not familiar with these techniques.

\section{HISTORICAL PERSPECTIVE}

Following the discovery of cocaine and description of its local anesthetic effects, Koller (4) reported the clinical use of cocaine as a topical anesthetic for ocular surgery in 1884. In 1899, Bier (5) described surgical anesthesia with the spinal injection of cocaine. In 1907, Schlösser (6) reported the percutaneous injection of $80 \%$ alcohol into sensory nerves to treat chronic pain in patients with trigeminal neuralgia. The introduction of these clinical techniques, together with the advent of safer local anesthetics such as procaine in 1905 and tetracaine in 1932, stimulated enthusiasm and the clinical development of neural blockade techniques, leading to more widespread use in pain management (7). However, in 1954, Vandam and Eckenhoff (8) proposed a shift in emphasis from analgesic nerve blocks to a more integrated approach aimed at understanding the fundamental nature of pain. This led to the establishment of multidisciplinary pain clinics in the 1960s (9) and a more critical outlook on the role of nerve blocks in pain management, as discussed by Bonica (10) at the first international symposium on pain in 1973. Although neural blockade continues to be used for chronic pain, evidence of efficacy is lacking, and further research is necessary to clarify its proper role in the clinic (11-13).

\section{PHYSIOLOGY AND PHARMACOLOGY OF NEURAL BLOCKADE}

\section{Neurophysiology of pain transmission}

Painful stimuli are transmitted from the periphery to the spinal cord via specialized, sensory nociceptive neurons. The cell bodies of these afferent neurons reside in the segmental dorsal root ganglia and their axons project peripherally to skin, muscle, bone and viscera, and centrally to the spinal cord dorsal horn (Figure 1). Peripheral nerve endings are structurally and functionally diverse such that they respond to thermal, mechanical or chemical noxious stimuli (14). According to the Erlanger/Gasser (15) classification, which characterizes peripheral nerve fibres according to their state of myelination, diameter and conduction velocity, nociceptive information is normally transmitted by A-delta and C fibres. Myelinated axons are surrounded by Schwann cells that are wrapped many times around the axon and provide electrical insulation. The continuity of the myelin sheath is interrupted at the nodes of Ranvier, spaced at interval lengths, where the axonal membrane is in direct contact with extracellular fluid. A-delta fibres are myelinated, small diameter ( 1 to $5 \mu \mathrm{m}$ ), medium velocity ( 12 to $30 \mathrm{~m} / \mathrm{s}$ ) neurons, and C fibres are unmyelinated, very small (less than $1 \mu \mathrm{m}$ ), slow velocity ( 0.5 to $2 \mathrm{~m} / \mathrm{s}$ ) neurons. Postganglionic, efferent sympathetic fibres that mediate vasoconstriction course within somatic and visceral nerves and may play a role in some chronic pain syndromes (16). A-beta fibres (myelinated, large, high velocity) normally transmit touch and pressure; however, certain pathological alterations (eg, following nerve injury) may result in pain transmission via these neurons (17).

Activation of a peripheral nerve ending by a noxious stimulus produces an electrical impulse called an action potential. A relevant stimulus alters axonal membrane permeability to sodium and potassium ions, resulting in nerve depolarization (18). Depolarization is associated with an outward potassium current and an inward sodium current through voltage-gated sodium ion channels that brings the membrane potential from a resting level of $-70 \mathrm{mV}$ to a positive value of approximately $30 \mathrm{mV}$. In unmyelinated axons, the action potential travels relatively slowly as a uniform wave along the length of the fibre. In myelinated axons, membrane depolarization occurs only at the nodes of Ranvier and impulse propagation occurs more rapidly by the passive 

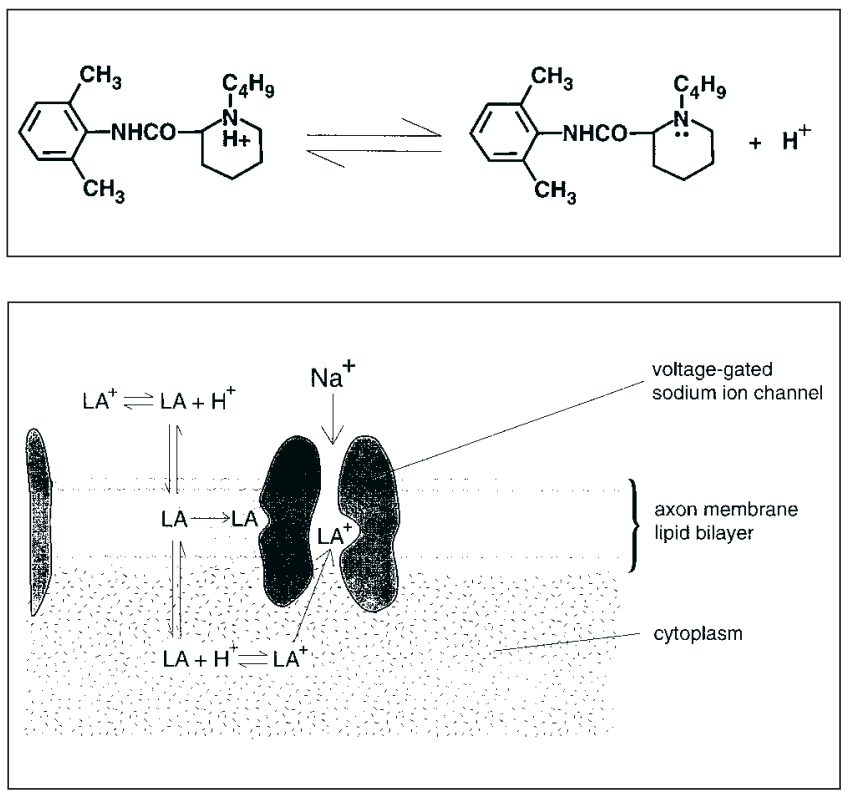

Figure 2) Mechanism of action of local anesthetics. Top The local anesthetic molecule, bupivicaine, in equilibrium between its protonated charged form and basic uncharged form. Bottom The uncharged form of the local anesthetic (LA) gains easy access to the lipid bilayer and binds to the membrane side of the sodium channel. The charged form ( $\left.\mathrm{LA}^{+}\right)$accesses the cytoplasm from where it binds to another site on the inner aspect of the sodium channel. Binding to the sodium channel inhibits the conformational changes that normally mediate cell depolarization, thus blocking nerve impulse conduction

spread of the current from node to node in a process called saltatory conduction.

\section{Pharmacological mechanisms of local anesthetics}

Through scores of sophisticated electrophysiological studies, the mechanism of action of local anesthetics was determined to be via the blockade of voltage-gated sodium ion channels in the axonal membrane (19). Clinically used local anesthetics are compounds classified as tertiary amine bases. These weak bases consist of a tertiary amine group that is linked to an aromatic group by an ester linkage (the ester local anesthetics, eg, cocaine and tetracaine) or an amide linkage (the amide local anesthetics, eg, lidocaine and bupivicaine). As weak bases, local anesthetics exist in an equilibrium between the protonated charged form and the basic uncharged form (Figure 2, top). When deposited onto a peripheral nerve, local anesthetics diffuse across and equilibrate within the axonal membrane lipid bilayer and the aqueous cytoplasm. The uncharged, hydrophobic form of the drug gains easy access to the lipid bilayer and interacts with a local anesthetic binding site, likely the most important one, on the membrane side of the voltage-gated sodium ion channel (Figure 2, bottom). The charged, more hydrophilic form of the drug gains easy access to the cytoplasm where it interacts with yet another local anesthetic binding site on the inner pore side of the sodium channel. Local anesthetic binding to the sodium channel inhibits the conformational changes that
TABLE 1

Chronic pain mechanisms potentially affected by neural blockade

\begin{tabular}{cc}
\hline Mechanism & Functional consequence \\
\hline $\begin{array}{c}\text { Neuroma formation and/or } \\
\text { proliferation of sodium } \\
\text { channels at nerve injury site }\end{array}$ & $\begin{array}{c}\text { Spontaneous shooting pains, } \\
\text { paresthesias (increased } \\
\text { nociceptor activity may lead } \\
\text { to central sensitization) }\end{array}$ \\
$\begin{array}{c}\text { Ectopic firing of nociceptors at } \\
\text { level of dorsal root ganglion } \\
\text { following nerve injury }\end{array}$ & $\begin{array}{c}\text { Spontaneous shooting pains, } \\
\text { paresthesias (increased } \\
\text { nociceptor activity may lead } \\
\text { to central sensitization) } \\
\text { terminals toward dorsal } \\
\text { horn superficial laminae } \\
\text { following nerve injury }\end{array}$ \\
$\begin{array}{c}\text { Sympathetic fibre sprouting and } \\
\text { increased expression of } \\
\text { alpha-adrenergic receptors }\end{array}$ & $\begin{array}{c}\text { (allodynia) } \\
\text { Spontaneous pain, } \\
\text { spmpathetically maintained }\end{array}$ \\
\hline
\end{tabular}

normally mediate cell depolarization and thus blocks nerve impulse conduction (19).

It has long been clinically observed that local anesthetics exert a differential block on various peripheral nerve functions. For example, the onset of an anesthetic injection generally produces a temporal progression of blockade, ie, loss of sympathetic function (eg, vasodilation) followed by loss of pin-prick sensation, light touch and temperature, and finally loss of motor function (20). This pattern of action has distinct advantages such as during epidural anesthesia for labour and delivery, where the use of bupivicaine results in effective sensory block while preserving motor function. The neurophysiological explanation for the differential block was initially thought to be related to differences in fibre thickness; however, discrepancies between laboratory and clinical studies leave this question unresolved (21).

\section{HOW DO NERVE BLOCKS AFFECT CHRONIC PAIN?}

Underlying processes leading to chronic pain are often unclear. In many situations, pain may be associated with longstanding changes in sensory processing by the peripheral and central nervous systems as well as psychological factors that further complicate evaluation and management. However, recently identified pathophysiological processes, particularly those following nerve injury, may be affected by neural blockade (Table 1).

\section{Central sensitization}

Evidence from experimental and clinical studies suggests that nociceptive transmission causes sensitization of spinal neurons, resulting in an exaggerated response to, and a decreased threshold for, subsequent noxious stimulation, and that these changes play a role in chronic pain syndromes (22). Pre-emptive analgesia, the concept that suppressing nociceptive transmission can prevent or diminish these changes, has 
TABLE 2

Anatomical classification of nerve blocks in chronic pain

\begin{tabular}{|c|c|c|c|}
\hline $\begin{array}{l}\text { Type of nerve } \\
\text { block }\end{array}$ & Site of injection & $\begin{array}{l}\text { Procedure } \\
\text { (illustrative } \\
\text { examples) }\end{array}$ & $\begin{array}{l}\text { Common } \\
\text { indication }\end{array}$ \\
\hline Local infiltration & Intramuscular & $\begin{array}{l}\text { Trigger point } \\
\text { injection }\end{array}$ & $\begin{array}{l}\text { Myofascial pain } \\
\text { syndrome }\end{array}$ \\
\hline \multirow[t]{2}{*}{ Somatic nerve* } & Peripheral nerve & $\begin{array}{l}\text { Ilioinguinal } \\
\text { nerve block }\end{array}$ & $\begin{array}{c}\text { Genitofemoral } \\
\text { neuralgia }\end{array}$ \\
\hline & & $\begin{array}{l}\text { Suprascapular } \\
\text { nerve block }\end{array}$ & $\begin{array}{l}\text { Rotator cuff } \\
\text { injury }\end{array}$ \\
\hline Somatic plexus* & Brachial plexus & $\begin{array}{c}\text { Brachial plexus } \\
\text { block }\end{array}$ & $\begin{array}{l}\text { Upper extremity } \\
\text { cancer pain }\end{array}$ \\
\hline Visceral plexus* & Celiac plexus & $\begin{array}{l}\text { Celiac plexus } \\
\text { block }\end{array}$ & $\begin{array}{l}\text { Pancreatic } \\
\text { cancer pain }\end{array}$ \\
\hline \multirow[t]{2}{*}{$\begin{array}{c}\text { Sympathetic } \\
\text { ganglion }\end{array}$} & $\begin{array}{l}\text { Cervical } \\
\text { sympathetic } \\
\text { chain }\end{array}$ & Stellate block ${ }^{\dagger}$ & $\begin{array}{l}\text { Complex } \\
\text { regional pain } \\
\text { syndrome }\end{array}$ \\
\hline & $\begin{array}{l}\text { Lumbar } \\
\text { sympathetic } \\
\text { chain }\end{array}$ & $\begin{array}{l}\text { Lumbar } \\
\text { sympathetic } \\
\text { block }\end{array}$ & $\begin{array}{l}\text { Complex } \\
\text { regional pain } \\
\text { syndrome }\end{array}$ \\
\hline \multirow[t]{2}{*}{ Epidural* } & Epidural space & $\begin{array}{l}\text { Lumbar } \\
\text { epidural } \\
\text { injection }\end{array}$ & $\begin{array}{c}\text { Chronic low } \\
\text { back pain }\end{array}$ \\
\hline & & $\begin{array}{l}\text { Cervical } \\
\text { epidural } \\
\text { injection }\end{array}$ & $\begin{array}{l}\text { Chronic neck } \\
\text { pain }\end{array}$ \\
\hline Spinal* & $\begin{array}{c}\text { Intrathecal } \\
\text { (cerebrospinal } \\
\text { fluid) }\end{array}$ & Spinal injection & $\begin{array}{c}\text { Lower } \\
\text { extremity/pelvic } \\
\text { cancer pain }\end{array}$ \\
\hline
\end{tabular}

*Also involves an element of sympathetic blockade; ${ }^{\dagger}$ See Figure 3

received much attention in the setting of postoperative pain (23) but also may be relevant to the concept of interrupting neural activity and perpetuating chronic pain (24).

Certain changes observed following nerve injury may result in excessive and inappropriate firing of nociceptive neurons to cause spontaneous pain and lead to spinal sensitization (25). Neuromas are small tufts of regenerating nerve fibres that are observed to grow at the site of a nerve injury and accompany an excessive proliferation of sodium channels along the axon (26). Interrupting nerve transmission proximal to the site of these changes may block the pain and prevent spinal sensitization, at least for the duration of the nerve block. However, nerve injury may also result in ectopic firing in the cell body at the level of the dorsal root ganglion (26), in which case it would be necessary to block conduction even more proximally, for example, with a spinal or epidural block. Other pathophysiological mechanisms following nerve injury include the sprouting of sympathetic nerve fibres around nociceptor cell bodies and the new expression of alpha-adrenoreceptors on injured axons (27). These changes may lead to perpetuation of pain by efferent sympathetic activity, referred to as sympathetically maintained pain, which can be affected by blocking the conduction of sympathetic nerve fibres.

\section{CLINICAL RATIONALE FOR NEURAL BLOCKADE}

For descriptive purposes, nerve blocks can be classified according to the anatomical site of injection as local infiltrations, blocks of somatic nerve, somatic plexus, visceral plexus, sympathetic ganglion, and epidural or spinal (intrathecal) injections (28-37) (Table 2). Percutaneous needle access allows the delivery of local anesthetic or neurolytic agent solutions onto neural structures. Because sympathetic nerve fibres course within somatic and visceral nerves, somatic, visceral plexus, epidural and spinal blocks all produce an element of sympathetic blockade. Selective sympathetic blockade can be applied with injections along the cervical or lumbar sympathetic chains, or more peripherally with intravenous injections of adrenergic antagonists such as guanethidine or bretylium using a tourniquet technique $(38,39)$. Technical approaches to neural blockade also are used to deliver other drugs, as in the case of epidural steroid and spinal opioid injections (40-42). Reviewing the clinical rationale for nerve blocks is facilitated by classification according to intended clinical goals, ie, diagnostic, prognostic and therapeutic (43).

Anesthetic injections may be useful in localizing a particular source of pain. For example, immediate and complete relief of back pain following local anesthetic injection into a facet joint implicates that structure as the source of pain. Similarly, nerve blocks may help differentiate between somatic and visceral pain. For example, the lack of effect of somatic intercostal nerve blocks in a patient with chest pain points to a visceral rather than a somatic cause. Despite these apparently decisive examples, several limitations to the diagnostic utility of nerve blocks include the likelihood of a variable and unpredictable placebo response, communication problems, inappropriate measurement of pain intensity and relief, possibility of a 'false positive' result due to systemic effects of local anesthetics, and variability in the quality of the anesthetic block due to anatomical and/or technical issues (12). Evidence that casts doubt upon the utility of diagnostic blocks comes from two groups, one from Newcastle, Australia, and another from Baltimore, United States in the form of controlled clinical trials - both showing poor specificity of diagnostic nerve blocks in low back pain and sciatica $(44,45)$.

For the patient and the clinician, prognostic nerve blocks simulate the effects likely to follow a corresponding neurodestructive procedure and confirm the expected analgesic benefit. For example, a positive response to temporary paravertebral spinal nerve block may support the decision to perform a neurosurgical posterior rhizotomy (46). However, given the diagnostic limitations listed above and the potentially irreversible effects and complications of a neurodestructive procedure, extreme caution must be used when interpreting such responses.

Therapeutic nerve blocks with local anesthetics likely have a limited role in chronic pain management. Despite the brief duration (in the range of hours) of local anesthetic blocks, analgesic effects have often been observed to outlast the conduction block, sometimes by days or weeks (11). Rea- 


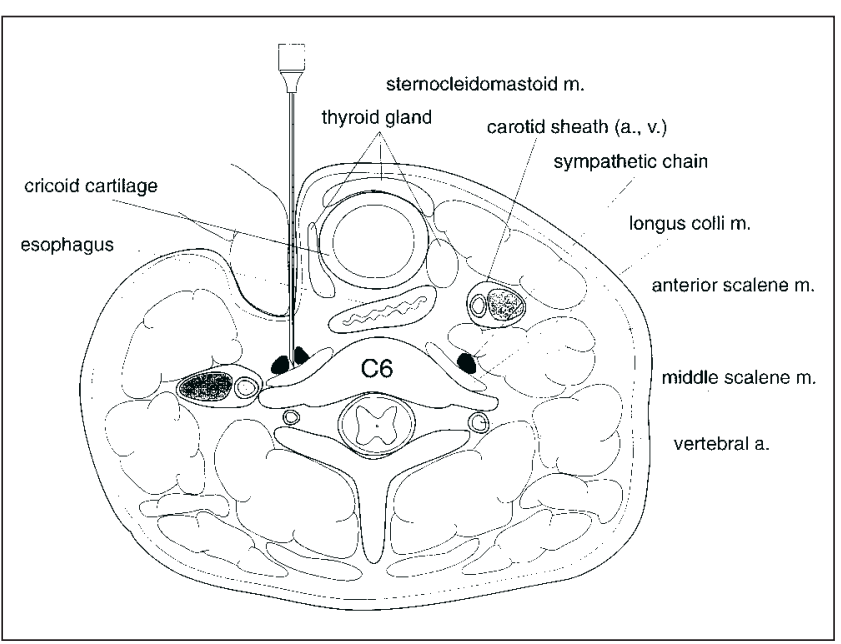

Figure 3) Stellate ganglion block. A thorough understanding of relevant anatomy is essential to performing nerve block injections such as blockade of the cervical sympathetic chain illustrated here. a Artery; m Muscle; v Jugular vein. Adapted with permission from reference 49 .

sons for this are unclear. In somatic conditions such as low back pain, this brief window of relief may help to break the vicious cycle of pain and facilitate physical therapy and rehabilitation. Temporary blocks also have been used to treat acute pain due to herpes zoster, although it is unclear whether they affect the development or severity of postherpetic neuralgia $(47,48)$.

\section{GENERAL PRINCIPLES OF NERVE BLOCK PROCEDURES}

Bonica and Butler (43) have outlined several principles of application for clinicians who perform nerve blocks to promote appropriate use and to optimize results in pain management. These principles include knowledge of pain syndromes and their applicable diagnostic measures, advantages, disadvantages and complications associated with indicated treatments; thorough evaluation of the patient's history, physical examination and relevant laboratory studies, even when referred by respected colleagues; maintenance of technical skills and thorough knowledge of the anatomical basis of the procedure, local anesthetic pharmacology and the necessary approaches for immediate treatment of possible complications (eg, resuscitation); thorough explanation to the patient of the procedure, and its purpose (ie, diagnostic versus therapeutic) and expected results; and careful evaluation and documention of the patient's response to the procedure.

Nerve blocks should be performed in a monitored setting with readily available equipment for cardiopulmonary resuscitation. As well, practitioners should have a thorough knowledge of local anesthetic pharmacology and maximal safe doses for each drug. The common technique of percutaneous needle injection involves a sterile approach by cleaning the skin surrounding the injection site with an antiseptic solution and draping the area to provide a wide sterile environment. The skin and subcutaneous tissue superficial to the
TABLE 3

Complications of local anesthetic nerve blocks

\begin{tabular}{lc}
\hline Cause & Complication \\
\hline $\begin{array}{c}\text { Needle contact with nerve } \\
\text { Unintentional intravascular } \\
\text { injection or excessive dose } \\
\text { of local anesthetic }\end{array}$ & $\begin{array}{c}\text { Nerve dysfunction, neuralgia } \\
\text { (confusion, seizures, may } \\
\text { lead to cardiac arrest) }\end{array}$ \\
$\begin{array}{c}\text { Hypersensitivity or allergy to } \\
\text { local anesthetic }\end{array}$ & $\begin{array}{c}\text { Hypersensitivity or anaphylactic } \\
\text { reaction }\end{array}$ \\
$\begin{array}{c}\text { Unintentional lung puncture } \\
\text { Leak of cerebrospinal fluid } \\
\text { through dural puncture }\end{array}$ & $\begin{array}{c}\text { Pneumothorax } \\
\text { Very high or total spinal } \\
\text { anesthetic }\end{array}$ \\
$\begin{array}{c}\text { Epidural abscess or hematoma } \\
\text { Pypotension, respiratory arrest }\end{array}$ \\
\hline
\end{tabular}

injection site should be anesthetized by local infiltration with dilute local anesthetic through a thin (25 to 30 gauge) needle. The patient should be warned before each step of the procedure, eg, before needle insertion, to minimize unexpected distress. The neural structure to be blocked may be localized by eliciting paresthesias with the needle, by using a nerve stimulator to elicit a motor response, or for deeper structures such as the celiac plexus, with the aid of radiographic equipment (40). As an illustrative example, Figure 3 describes the anatomical aspects of performing a nerve block of the cervical sympathetic chain, referred to as a stellate ganglion block (49).

\section{ADVERSE EFFECTS AND COMPLICATIONS}

Serious complications of local anesthetic nerve blocks, though rare, have been reported (40) (Table 3). The potential for such complications underscores the necessity to perform these procedures in a monitored environment with well trained personnel to respond appropriately. Also, these risks further emphasize the importance of carefully evaluating the risk-benefit profile of nerve blocks in each individual.

\section{PERMANENT BLOCKADE WITH NEUROLYTIC AGENTS}

In select circumstances where diagnostic temporary blockade has proven helpful, neurolytic agents may be applied to impair or permanently destroy a nerve. Clinical agents used for neurolytic blockade include alcohols such as ethanol and phenol. Other neurodestructive procedures include radiofrequency thermocoagulation, cryoneurolysis and ionizing radiation $(50,51)$.

Topical administration of alcohols such as $100 \%$ ethanol results in the extraction of cholesterol, phospholipids and cerebrosides from the nerve causing the coagulation of lipoproteins and mucoproteins (52), leading to a destructive process called Wallerian degeneration (53). This process 
involves axonal breakdown and hydrolysis by lysosomal enzymes, coupled with a proliferation of surrounding Schwann cells and a corresponding interruption in peripheral nerve conduction. Axonal regeneration begins days to weeks after the initial insult and functional recovery depends on the degree of damage to the endoneurium.

Potentially devastating, although infrequent, complications of neurolytic injections include unwanted sympathetic, sensory or motor block due to extravasation or malplacement of the solution onto other nerves and anesthesia dolorosa, the development of intractable pain in the anesthetic area (50). Furthermore, neurolytic blockade is not permanent, and pain may return within weeks to months after the procedure. For these reasons, treatment with neurolytic blocks are generally restricted to patients with malignant pain and limited life expectancy, following a clear demonstration of benefit with a diagnostic block (54). One of the most common and useful applications of neurolytic blockade is the celiac plexus block. This procedure is used to treat visceral pain related to cancer of the pancreas (32).

\section{EVIDENCE FOR EFFICACY OF TEMPORARY OR PERMANENT NERVE BLOCKS}

Levels of evidence for health interventions include metaanalyses or systematic reviews of randomized, controlled trials (RCTs), one or more individual RCTs, case-control or cohort studies, and expert opinion based on case series, individual cases or experimental evidence (55). Neurolytic celiac plexus block (NCPB) for upper abdominal cancer pain is the neural blockade procedure, perhaps, for which the strongest evidence exists. In 1995, Eisenberg and colleagues (56) published a meta-analysis of 59 reports of NCPB. Twenty-four of these reports included the experience of at least two patients; two were prospective RCTs, one was a prospective, uncontrolled study and 21 were retrospective studies. Based on this analysis, the authors concluded that NCPB imparts long lasting benefit in $70 \%$ to $90 \%$ of patients with upper abdominal cancer and is associated with common, mild and transient adverse effects such as local pain and diarrhea. Weaker evidence supporting neurolytic lumbar

\section{REFERENCES}

1. Cousins MJ, Bridenbaugh PO, eds. Neural blockade in clinical anesthesia and management of pain, 3rd edn. Philadelphia: Lippincott Williams \& Wilkins, 1998.

2. Ready LB. Acute postoperative pain. In: Miller RD, ed. Anesthesia, 3rd edn. New York: Churchill Livingstone, 1990:2135-46.

3. Bonica JJ. Regional anlagesia/anesthesia: Introduction. In: Bonica JJ, ed. The management of pain, 2nd edn. Malvern: Lea \& Febiger, 1990:1878-82.

4. Koller C. On the use of cocaine for producing anaesthesia on the eye. Lancet 1884;ii:990.

5. Bier A. Versuche über Cocainisirung des Rückenmarkes. Dtsch Z Chir 1899;5151:361.

6. Schlösser H. Erfahrungen in der Neuralgiebehandlung mit Alkoholeinspritzungen. Verh Cong Innere Med 1907;24:49. sympathetic block for patients with rest pain and skin ulceration, because of peripheral vascular disease, comes in the form of a case series of 386 patients. Among these patients, relief was demonstrated completely in $49 \%$, partially in $31 \%$ and ineffectively in $20 \%$ (57). The application of lumbar sympathetic or stellate ganglion temporary blocks in the treatment of complex regional pain syndrome appears to provide satisfactory analgesia of prolonged duration in $46 \%$ of patients, based on a review of seven studies (58) of over 500 patients altogether. However, these studies (58) used differing methods, techniques and criteria. Finally, a review of several case series and retrospective reports on the use of sympathetic nerve blocks for herpes zoster infection suggested a beneficial effect during the acute phase but was inconclusive regarding prevention of postherpetic neuralgia (47).

Methodological challenges to evaluating the efficacy of neural blockade for chronic pain syndromes include the identification of an appropriate placebo control intervention (24) and of ethical considerations for randomly assigning chronic pain patients to such a procedure. The research in this field continues and the evidence supporting efficacy of nerve blocks is currently under review by the Cochrane Pain, Palliative Care and Supportive Care Group (59).

\section{CONCLUSIONS}

Procedures that block nerve conduction have been used for over a century and are relatively safe when performed by technically experienced clinicians who are knowledgeable in the diagnosis and management of chronic pain syndromes. Well designed, carefully controlled clinical trials are necessary in order to evaluate rigorously the safety and efficacy of neural blockade for specific painful conditions.

ACKNOWLEDGMENTS: Supported in part by Intramural Project Grants from the National Institute of Dental and Craniofacial Research, Bethesda, Maryland, USA. Many thanks to Dr Mitchell Max and Dr Ken Kardash for their thoughtful comments on previous versions of this manuscript.

7. Rovenstine EA, Wertheim HM. Therapeutic nerve blocks. JAMA 1941;117:1599.

8. Vandam LD, Eckenhoff JE. The anaesthesiologist and therapeutic nerve block: technician or physician? Anesthesiology 1954;15:89.

9. Bonica JJ. Basic principles in managing chronic pain. Arch Surg 1977;112:783-8.

10. Bonica JJ. Current role of nerve blocks in diagnosis and therapy of pain. In: International Symposium on Pain. Advances in Neurology 1973;4:445-53.

11. Arner S, Lindblom U, Meyerson BA, Molander C. Prolonged relief of neuralgia after regional anesthetic blocks. A call for further experimental and systematic clinical studies. Pain 1990;43:287-97.

12. Hogan QH, Abram SE. Neural blockade for diagnosis and prognosis. A review. Anesthesiology 1997;86:216-41.

13. Raja SN. Nerve blocks in the evaluation of chronic pain. A plea 
for caution in their use and interpretation. Anesthesiology 1997;86:4-6.

14. Yaksh TL, Hammond DL. Peripheral and central substrates involved in the rostral transmission of nociceptive information. Pain 1982;13:1-85.

15. Gasser HS. Pain-producing impulses in peripheral nerves. Proc A Res Nerv Ment Dis 1943;23:44.

16. Roberts WJ. A hypothesis on the physiological basis for causalgia and related pains. Pain 1986;24:297.

17. Woolf CJ, Doubell TP. The pathophysiology of chronic pain increased sensitivity to low threshold A beta-fibre inputs. Curr Opin Neurobiol 1994;4:525-34.

18. Hodgkin AL, Huxley AF. A quantitative description of membrane current and its application to conduction and excitation in nerve. J Physiol 1952;117:500.

19. Strichartz GR, Berde CB. Local anesthetics. In: Miller RD, ed. Anesthesia, 4th edn. New York: Churchill Livingstone, 1994:489-521.

20. Carpenter RL, Mackey DC. Local anesthetics. In: Barash PG, Cullen BF, Stoelting RK, eds. Clinical Anesthesia, 2nd edn. Philadelphia: Lippincott Williams \& Wilkins, 1992:509-41.

21. Fink BR, Cairns AM. Lack of size-related differential sensitivity to equilibrium conduction block among mammalian myelinated axons exposed to lidocaine. Anesth Analg 1987;66:948.

22. Coderre TJ, Katz J, Vaccarino AL, Melzack R. Contribution of central neuroplasticity to pathological pain: review of clinical and experimental evidence. Pain 1993;52:259-85.

23. Woolf CJ, Chong MS. Pre-emptive analgesia - treating postoperative pain by preventing the establishment of central sensitization. Anesth Analg 1993;77:362-79.

24. Wall PD. New horizons: An essay. In: Cousins MJ, Bridenbaugh PO, eds. Neural blockade in clinical anesthesia and management of pain, 3rd edn. Philadelphia: Lippincott Williams \& Wilkins, 1998:1135-43.

25. Woolf CJ, Mannion RJ. Neuropathic pain: aetiology, symptoms, mechanisms, and management. Lancet 1999;353:1959-64.

26. Devor M. The pathophysiology of damaged peripheral nerves. In: Wall PD, Melzack R, eds. Textbook of Pain, 3rd edn. Edinburgh: Churchill Livingstone, 1994:79-100.

27. Jänig W, Levine JD, Michaelis M. Interactions of sympathetic and primary afferent neurons following nerve injury and tissue trauma. Prog Brain Res 1996;113:161-84.

28. Ready LB, Kozody R, Barsa JE, Murphy TM. Trigger pont injections vs jet injection in the treatment of myofascial pain. Pain 1989;15:201-6.

29. Harms BA, DeHaas DR Jr, Starling JR. Diagnosis and management of genitofemoral neuralgia. Arch Surg 1984;119:339-41.

30. Vecchio PC, Adebajo AO, Hazleman BL. Suprascapular nerve block for persistent rotator cuff lesions. J Rheumatol 1993;20:453-5.

31. Clarke AJ, Simpson KH, Ellis FR. Continuous brachial plexus block in the management of intractable cancer pain in the arm. Palliative Med 1990;4:123-5.

32. Flanigan DP, Kraft RO. Continuing experience with palliative chemical splanchnicectomy. Arch Surg 1978;113:509-11.

33. Linson MA, Leffert R, Todd DP. The treatment of upper extremity reflex sympathetic dystrophy with prolonged continuous stellate ganglion blockade. J Hand Surg 1983;8:153-9.

34. Walsh JA, Glynn CJ, Cousins MJ, Basedow RW. Blood flow, sympathetic activity and pain relief following lumbar sympathetic blockade or surgical sympathectomy. Anaesth Intensive Care 1985;13:18-24.

35. Breivik H, Hesla PE, Molnar I, Lind B. Treatment of chronic low back pain and sciatica: comparison of caudal epidural injections of bupivacaine and methylprednisolone with bupivacaine followed by saline. In: Bonica JJ, ed. Advances in Pain Research and Therapy. New York: Raven Press, 1977:927-32.

36. Catchlove RF, Braha R. The use of cervical epidural nerve blocks in the management of chronic head and neck pain. Can Anaesth Soc J 1984;31:188-91.

37. van Dongen RT, Crul BJ, van Egmond J. Intrathecal coadministration of bupivacaine diminishes morphine dose progression during long-term intrathecal infusion in cancer patients. Clin J Pain 1999;15:166-72.

38. Hannington-Kiff JG. Intravenous regional sympathetic block with guanethidine. Lancet 1974;1:1019-20.

39. Hord AH, Rooks MD, Stephens BO, Rogers HG, Fleming LL. Intravenous regional bretylium and lidocaine for treatment of reflex sympathetic dystrophy: A randomized, double-blind study. Anesth Analg 1992;74:818-21.

40. Bonica JJ, Buckley FP. Regional analgesia with local anesthetics. In: Bonica JJ, ed. The Management of Pain, 2nd edn. Malvern: Lea \& Febiger, 1990:1883-966.

41. Ready LB. Regional analgesia with intraspinal opioids. In: Bonica JJ, ed. The Management of Pain, 2nd edn. Malvern: Lea \& Febiger, 1990:1967-79.

42. Koes BW, Scholten RJPM, Mens JMA, Bouter LM. Efficacy of epidural steroid injections for low back pain and sciatica: a systematic review of randomized clinical trials. Pain 1995;63:279-88.

43. Bonica JJ, Butler SH. Local anaesthesia and regional blocks. In: Wall PD, Melzack R, eds. Textbook of Pain, 3rd edn. Edinburgh: Churchill Livingstone, 1994:997-1023.

44. Schwarzer AC, Aprill CN, Derby R, Fortin J, Kine G, Bogduk N. The false-positive rate of uncontrolled diagnostic blocks of the lumbar zygapophysial joints. Pain 1994;58:195-200.

45. North RB, Kidd DH, Zahurak M, Piantadosi S. Specificity of diagnostic nerve blocks: a prospective, randomized study of sciatica due to lumbosacral spine disease. Pain 1996;65:77-85.

46. Loeser JD. Dorsal rhizotomy for the relief of chronic pain. J Neurosurg 1972;36:745.

47. Ali NMK. Does sympathetic ganglionic block prevent postherpetic neuralgia? Reg Anesth 1995;20:227-33.

48. Hwang SM, Kang YC, Lee YB, Yoon KB, Ahn SK, Choi EH. The effects of epidural blockade on the acute pain in herpes zoster. Arch Dermatol 1999;135:1359-64.

49. Brown DL. Atlas of regional anesthesia. Philadelphia: WB Saunders, 1992:175-8.

50. Patt RB, Cousins MJ. Techniques for neurolytic neural blockade. In: Cousins MJ, Bridenbaugh PO, eds. Neural Blockade in Clinical Anesthesia and Management of Pain, 3rd edn. Philadelphia: Lippincott Williams \& Wilkins, 1998:1007-61.

51. Waldman SD, Winnie AP, eds. Interventional pain management. Philadelphia: WB Saunders, 1996.

52. Rumsby MG, Finean JB. The action of organic solvents on the myelin sheath of peripheral nerve tissue-II (short chain aliphatic alcohols). J Neurochem 1966;13:1509.

53. Waller A. Experiments of the section of the glossopharyngeal and hypoglossal nerves of the frog and observations of the alterations produced thereby in the structure of their primitive fibres. Philos Trans R Soc 1850;140:423. 
54. Raj PP. Peripheral neurolysis in the management of pain. In: Waldman SD, Winnie AP, eds. Interventional Pain Management. Philadelphia: WB Saunders, 1996:392-400.

55. Guyatt GH, Sackett DL, Cook DJ. User's guides to the medical literature. II. How to use an article about therapy or prevention. B. What were the results and will they help me in caring for my patients? Evidence-Based Medicine Working Group. JAMA 1994;271:59-63.

56. Eisenberg E, Carr DB, Chalmers TC. Neurolytic celiac plexus block for treatment of cancer pain: a meta-analysis. Anesth Analg 1995;81:213.

57. Cousins MJ, Reeve TS, Glynn CJ, Walsh JA, Cherry DA.
Neurolytic lumbar sympathetic blockade: duration of denervation and relief of rest pain. Anaesth Intensive Care 1979;7:121-35.

58. Kozin F. Reflex sympathetic dystrophy syndrome: a review. Clin Exp Rheumatol 1992;10:401-9.

59. Carr DB, Wiffen P, Fairman F, LeMaitre M. The Cochrane collaboration and its pain, palliative and supportive care review group. In: Max MB, ed. Pain 1999 - an updated review. Seattle: IASP Press, 1999:399-410.

60. Bonica JJ. Anatomic and physiologic basis of nociception and pain. In: Bonica JJ, ed. The management of pain, 2nd edn. Malvern: Lea \& Febiger, 1990:30. 


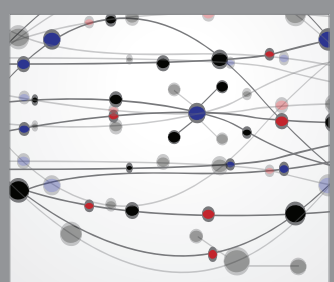

The Scientific World Journal
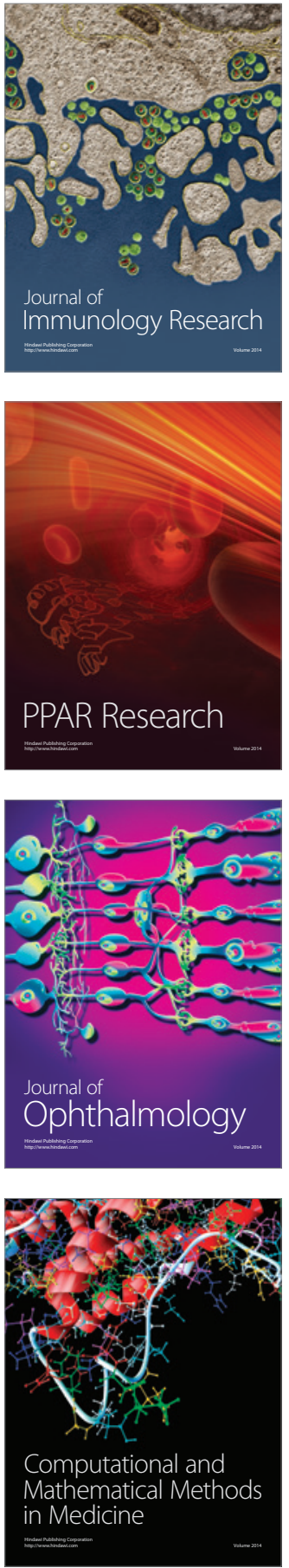

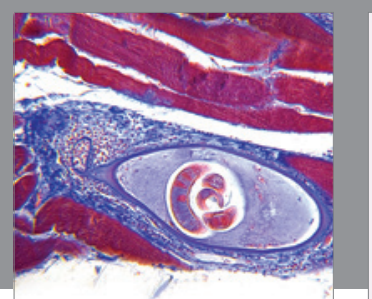

Gastroenterology Research and Practice

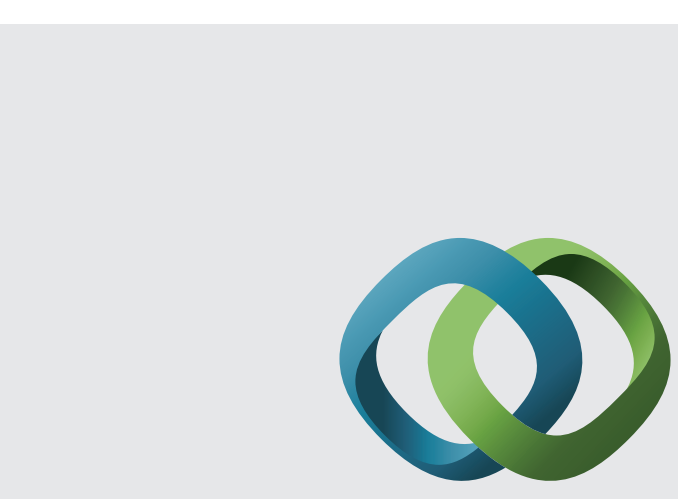

\section{Hindawi}

Submit your manuscripts at

http://www.hindawi.com
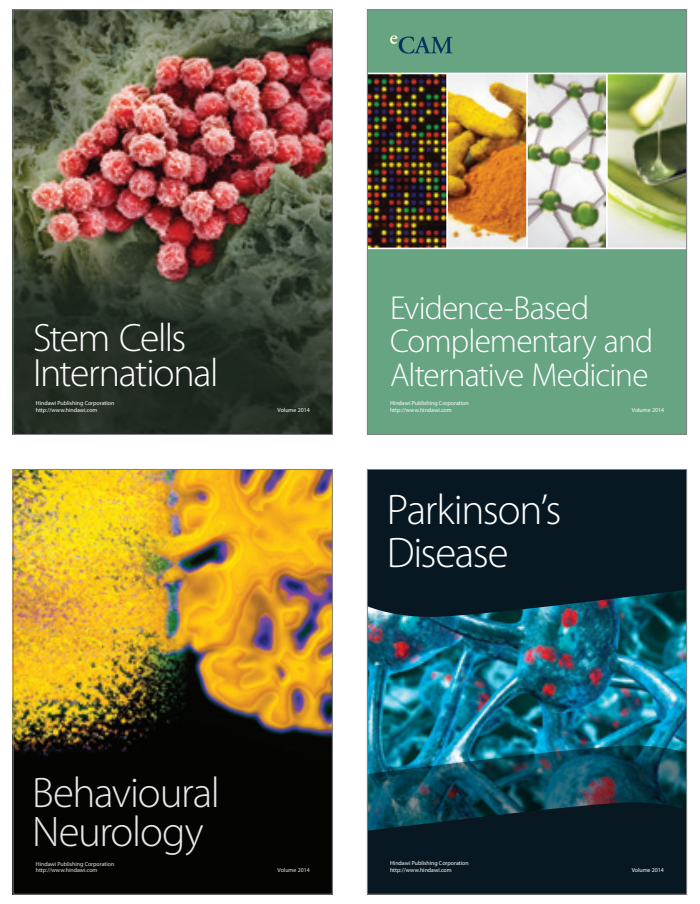
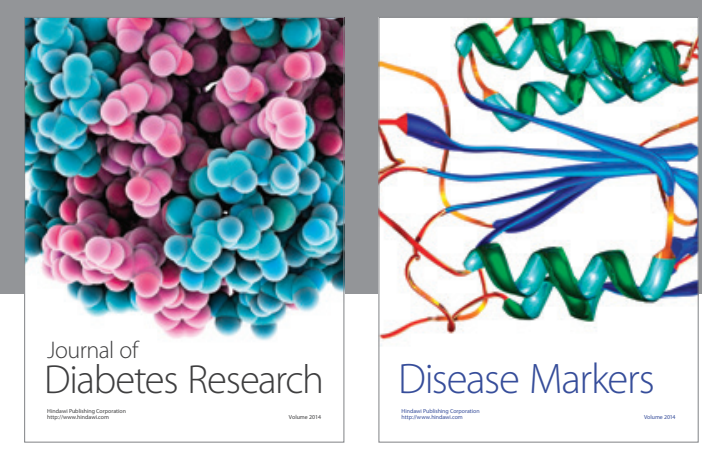

Disease Markers
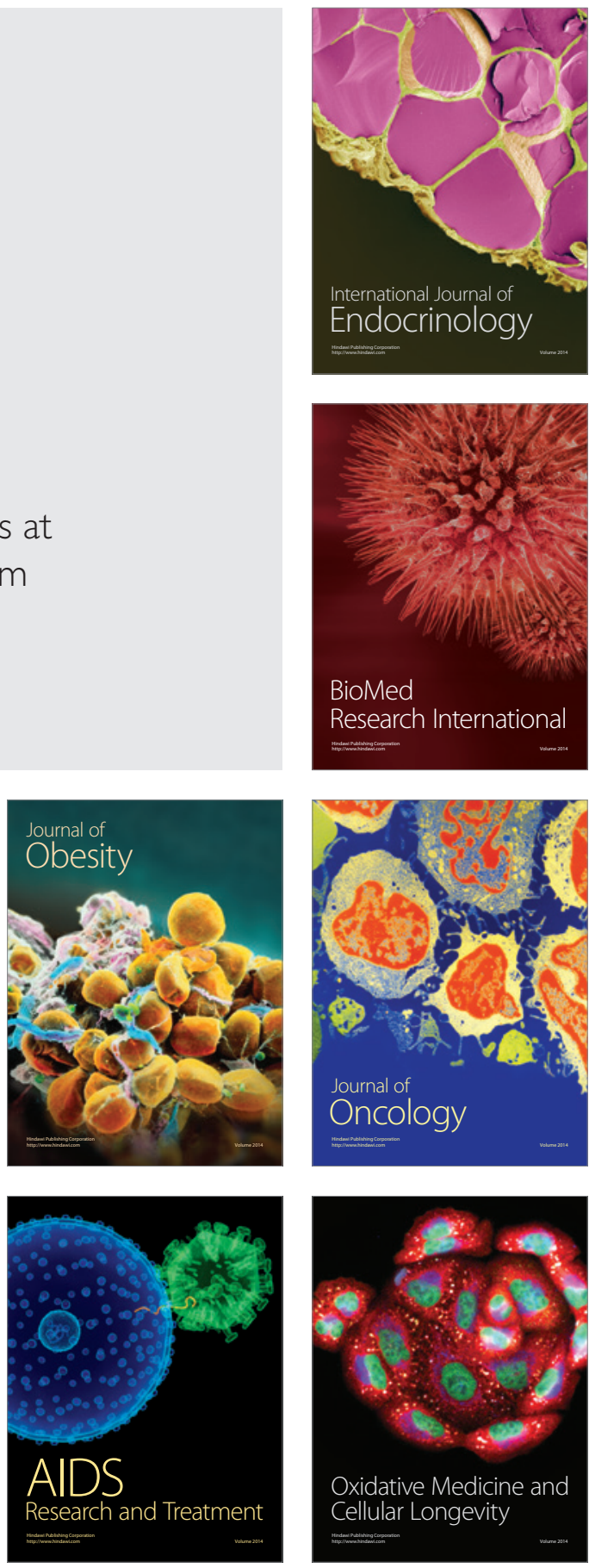